\title{
In-Vitro Effect of Sex Steroids on Mouse Melanoma (B16F10) Cell Growth
}

\author{
Pandurangan Ramaraj; , James L. Cox \\ Department of Biochemistry, Kirksville College of Osteopathic Medicine, A.T. Still University of Health Sciences, \\ Kirksville, Missouri, USA \\ Email: ${ }^{*}$ pramaraj@atsu.edu
}

Received 4 May 2014; revised 4 June 2014; accepted 11 June 2014

Copyright (C) 2014 by authors and Scientific Research Publishing Inc.

This work is licensed under the Creative Commons Attribution International License (CC BY).

http://creativecommons.org/licenses/by/4.0/

(c) (i) Open Access

\section{Abstract}

A battery of sex steroids were used to check their effect on mouse melanoma (B16F10) cell growth in-vitro. Progesterone and its synthetic receptor antagonist RU-486 showed maximum inhibition on in-vitro melanoma cell growth [1]. Further research work showed that the inhibition by progesterone was not a toxic, spurious or non-specific effect on mouse melanoma cell growth and the inhibition by progesterone was not mediated through progesterone receptor.

\section{Keywords}

\section{Sex Steroids, B16 Mouse Melanoma, MTT Growth Assay}

\section{Introduction}

Skin is not only a target organ for sex hormones, but also synthesizes significant amount of sex hormones locally [2]. Several functions of human skin appear strongly dependent on these sex hormones viz. androgens, estrogen and progestins [3]. Androgens such as dehydroepiandrosterone (DHEA), DHEA sulfate (DHEAS) and androstenedione (AD) are weak prohormones that act after conversion to the more potent testosterone (T) and 5- $\alpha$ dihydrotestosterone (DHT). Androgens affect sebaceous gland growth and differentiation, hair growth, epidermal barrier homeostasis and wound healing, acne, seborrhea, hirsutism and androgenetic alopecia. On the other hand, estrogens have been implicated in skin aging, pigmentation, hair growth, sebum production and skin cancer. In contrast progestins play no role in the pathogenesis of skin disorders. Progestins, however, play a major role in the treatment of hirsutism and acne vulgaris. Progesterone also complements estrogen effect on fluid retention. Imbalances in hormones affect skin texture and cause skin diseases. One fatal form of skin disease is melanoma, cancer of the melanocytes in the skin [4]. Though melanoma is a rare form of skin cancer, yet it is a

${ }^{*}$ Corresponding author. 
dangerous form of skin cancer [4]. Since sex steroids are essential for healthy skin and melanoma is a serious skin disease, the relevant question at this junction is about the effect of sex steroids on melanoma growth. The possible dependence of human melanoma on endocrine influences has been speculated upon for many years [5]-[7]. But there is a lack of systematic study on the direct effect of sex steroids on melanoma growth. This information is vital because sex steroids such as estrogen, progesterone and testosterone are known to support breast, ovary and prostate cancers, even though these steroid hormones are essential for normal growth, development and function of these organs [8]-[10]. Whether the same is true for melanoma was not clear from literature survey of various experimental results for hormonal growth regulation of melanoma [11]-[15]. Hence, the aim of the study was to find out the direct effect of sex steroids on melanoma growth using mouse melanoma (B16F10) cell line as a model system.

\section{Materials and Methods}

\subsection{Chemicals}

Cholesterol, dehydroepiandrosterone (DHEA), androstenedione (AD) estrogen (E), progesterone (P), RU-486, dexamethasone (water soluble) were all purchased from Sigma Chemical Company, St. Louis, MO. MTT (3[4,5-Dimethylthiazol-2-yl]-2,5-diphenyl tetrazolium bromide), isopropanol, ethanol were also obtained from Sigma Chemical Company. Fetal bovine serum (FBS), Trypsin-EDTA $(1 \times)$, and PBS powder were purchased from Atlanta biologicals, Lawrenceville, GA. RPMI and antibiotic/antimycotic solution $(100 \times)(10,000 \mathrm{I} . \mathrm{U} / \mathrm{ml}$ penicillin, $10 \mathrm{mg} / \mathrm{ml}$ streptomycin, $25 \mu \mathrm{g} / \mathrm{ml}$ amphotericin B) were purchased from Fisher scientific, Houston, TX. SLT Spectra plate reader was used for quantitation of MTT assay.

\subsection{Cell Lines}

Mouse metastatic melanoma cell line B16F10 and human gastric cancer cell line NUGC3 were obtained from a colleague (Dr. James L. Cox) in the department. Sub-cultured normal rat vascular smooth muscle cells (VSMC) and the medium (DMEM/F12) to culture them were obtained from another colleague (Dr. Yingzi Chang) in the pharmacology department of KCOM.

\subsection{Growth Medium (GM)}

Medium used for cell culture. GM consisted of RPMI + 10\% FBS + 1X Pen/Strep/Ampho.

\subsection{Preparation of Steroid Hormones and MTT Solutions}

Initially $10 \mathrm{mM}$ stock solution of steroid hormones in ethanol were prepared. One mM working stock was made by diluting one part of alcohol stock with nine parts of GM. Different concentrations of hormones were made from $1 \mathrm{mM}$ working stock by serial dilution. MTT stock solution was made by dissolving $5 \mathrm{mg}$ in one $\mathrm{ml}$ of PBS.

\subsection{Cell Growth Assay}

MTT proliferation assay [16] was used to quantitate cell growth in treated (with various sex steroids) and in untreated (control) samples. In addition, microscopic pictures of cells treated with different hormones were taken to document hormonal effects at different concentrations on cell growth.

\subsection{MTT Proliferation Assay}

B16F10 cells were suspended in growth medium (GM) and plated at a density of $1 \times 10^{4}$ cells/well in a 96 well plate. Cells were left overnight at $37^{\circ} \mathrm{C}$ to attach to the plate. Following day growth medium was replaced by GM containing hormones at different concentrations and incubated for 48 hrs. After 48 hrs, medium was replaced with $100 \mu \mathrm{l}$ of 1 in 10 diluted (in GM) MTT solution and incubated for another 4 hrs at $37^{\circ} \mathrm{C}$. After 4 hrs, MTT solution was removed. MTT was reduced by metabolically viable cells to a colored (purple) water insoluble formazon salt. The purple color precipitate was solublized by adding $100 \mu \mathrm{l}$ of isopropanol and shaken for 20 - 30 mins at room temperature. Intensity of resultant purple color was measured at $570 \mathrm{~nm}$ in SLT spectra plate reader. The same protocol was followed for MTT assay with human gastric cancer (NUGC3) cell line. 


\subsection{MTT Assay with Sub-Cultured Normal Rat Vascular Smooth Muscle Cells}

Procedure for isolation of rat aortic vascular smooth muscle cells was described in reference [17]. A petri dish containing cells at 6/7 passage was obtained from a colleague. Cells were harvested from the plate using trypsinEDTA and were re-plated in a 96 well plate in DMEM/F12 medium. Cells were left for 2 - 3 days to become $70 \%$ to $80 \%$ confluent. Regular medium was replaced by medium containing different concentrations of progesterone and RU-486 and incubated for 48 hrs. At the end of 48 hrs, MTT assay was carried out to quantitate cell growth.

\subsection{Experiments}

Initially, MTT growth assays were carried out with dehydroepiandrosterone (DHEA), androstenedione (AD), testosterone ( $\mathrm{T}$ ) and progesterone (P) treated mouse melanoma (B16F10) cells to check their effect on cell growth at high concentrations $(100,150,200 \mu \mathrm{M})$. This was followed by dose-curve studies with progesterone, estrogen, RU-486 to determine whether the inhibition of cell growth was due to toxic effect of the steroids. Dose curve studies were also carried out with cholesterol and dexamethasone to determine whether the inhibition of cell growth was due to spurious effect of the steroids. For comparison sake as well as negative control to determine whether the effect on cell growth was due to non-specific effect of the steroids, dose curve studies of progesterone and RU-486 were carried out with human gastric cancer cell line (NUGC3) and also with sub-cultured normal rat vascular smooth muscle cells (VSMC). Finally a bioassay involving co-incubation of progesterone and its receptor antagonist RU-486 was carried out to determine whether progesterone action was mediated through its receptor.

\subsection{Statistical Analysis}

All the experimental points were carried out in triplicate ( 3 wells). Average of all the three values was taken as mean and standard error was calculated. Each experimental point was expressed as Mean \pm SEM. Two-way ANOVA analysis was carried out to find the dose and the sex hormone which showed significant inhibition on cell growth. One-way ANOVA analysis was used to compare the significance of cell growth inhibition between individual sex hormone and a combination of sex hormones. Each experiment was repeated a minimum of two times to check for consistency in results.

\section{Results}

\subsection{MTT Growth Assay to Check the Effect of Dehydroepiandrosterone (DHEA), Androstenedione (AD), Testosterone (T) and Progesterone (P) on Mouse Melanoma Cell Growth}

Initially four steroids (two weak androgens DHEA, AD and one strong androgen $\mathrm{T}$ and one female sex steroid P) were used to check their effect on mouse melanoma cell growth at 100, 150 and $200 \mu \mathrm{M}$ concentrations along with untreated control and alcohol control (as steroid hormones were dissolved in alcohol). Growth in untreated control well as measured by MTT assay was considered as $100 \%$. The growth in other wells was compared with untreated control well and expressed as \% of growth. Alcohol (2\%) treated cells did not show any difference from the untreated control cell growth. Though, all the four steroids showed dose-dependent inhibition of mouse melanoma cell growth, progesterone in particular showed a significant inhibition ( $87 \%$ at $200 \mu \mathrm{M}$ concentration) on melanoma cell growth (Figure 1). Two-way ANOVA analysis followed by post-hoc Bonferroni multiple comparison test showed that progesterone at 100 and $150 \mu \mathrm{M}$ concentrations inhibited melanoma cell growth significantly $(\mathrm{P}<0.001)$ than other sex steroids. Statistical analysis was given in a table form (Table 1$)$.

\subsection{Dose Curve Studies with Progesterone, Estrogen and RU-486 to Check for Toxic Effect of Steroids on Melanoma Cell Growth}

Since progesterone showed maximum inhibition on cell growth, it was decided to follow-up progesterone experiment to find out if the inhibition was due to toxic, spurious or non-specific effect on mouse melanoma cell growth. 


\section{$\mathrm{B} 16 \mathrm{~F} 10$}

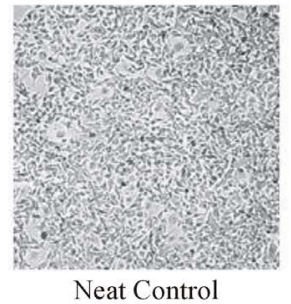

Neat Control

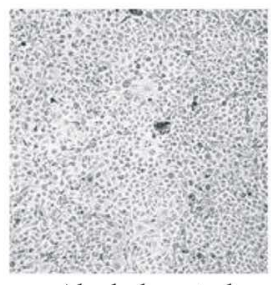

Alcohol control

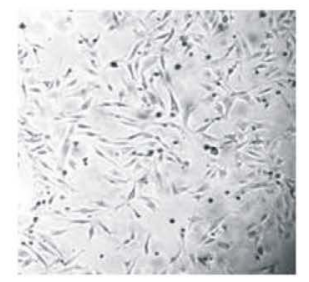

DHEA $150 \mu \mathrm{M}$

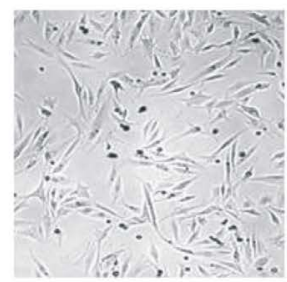

AD $150 \mu \mathrm{M}$
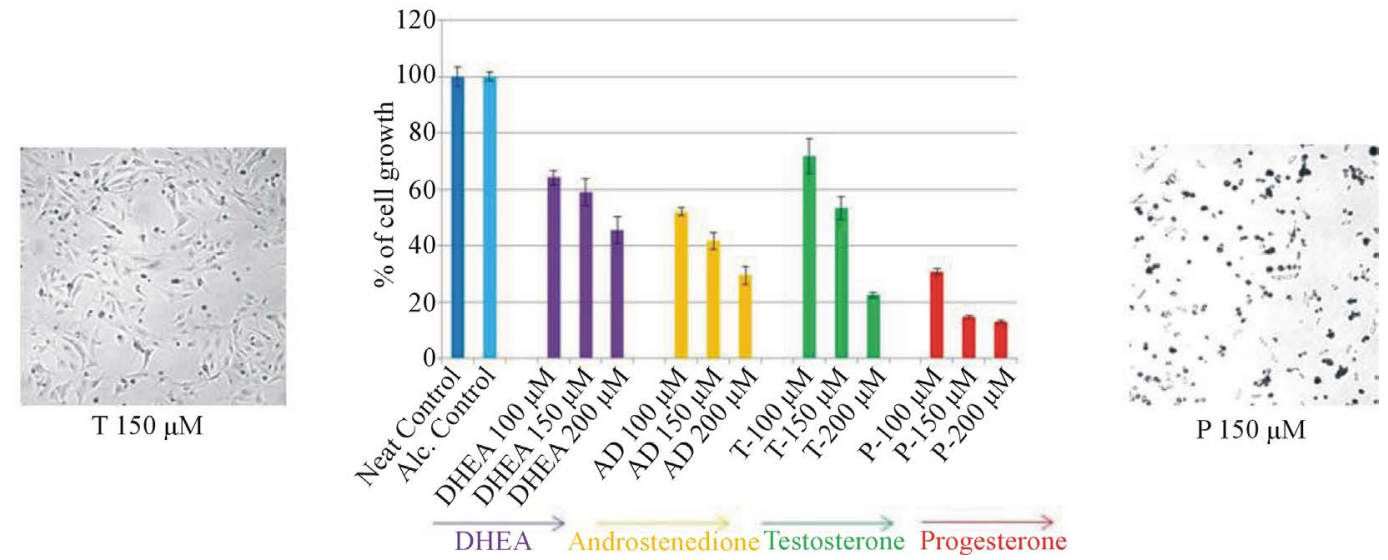

P $150 \mu \mathrm{M}$

DHEA Androstenedione Testosterone Progesterone

Figure 1. Effect of various steroids on mouse melanoma cell growth. B16F10 mouse metastatic melanoma cells were plated in 96 well plate. Androgens [dehydroepiandrosterone (DHEA), androstenedione (AD), testosterone (T)] and progesterone (P) were added at 100,150 and $200 \mu \mathrm{M}$ concentrations to cells. After 48 hrs of incubation, medium was removed and viable cells were quantitated by MTT assay. Among the four steroids tested, progesterone showed maximum inhibition (87\%) of mouse melanoma cell growth. Two-way ANOVA analysis showed that inhibition by progesterone at 100 and $150 \mu \mathrm{M}$ concentrations were significant when compared to DHEA, AD and T at different concentrations. Statistical data is shown in Table 1.

\subsubsection{Dose-Curve Study with Progesterone}

Since, P showed maximum inhibition of melanoma cell growth at high concentrations (100, 150 and $200 \mu \mathrm{M})$, further experiments were carried out to determine whether the inhibition by progesterone was due to toxicity of steroids. Dose-curve study of progesterone starting from $100 \mathrm{nM}$ to $200 \mu \mathrm{M}$ was carried out following the same protocol. Progesterone showed a dose-dependent inhibition of melanoma cell growth (sigmoidal curve), indicating it was a genuine biological effect on cell growth by progesterone (Figure 2(a)).

\subsubsection{Dose Curve Study with Estrogen}

Dose-curve study of progesterone, prompted us to carry out dose-curve study with estrogen the other sex steroid hormone in excess in females. Dose curve study with estrogen also served as a comparable standard to check for toxic effect of steroid. Estrogen also showed a dose-dependent inhibition on cell growth like progesterone. However, inhibition brought out by estrogen at high concentration was not as significant as the inhibition brought out by progesterone at high concentration (Figure 2(b)).

\subsubsection{Dose-Curve Study with Progesterone Receptor Antagonist Mifepristone (RU-486)}

It is the general understanding that all steroids including progesterone act through specific steroid receptors. In order to determine whether the inhibition by progesterone was mediated through progesterone receptor, dose curve study with progesterone receptor antagonist RU-486 was carried out. Before using RU-486 in the study, it was important to find out whether RU-486 itself had any effect on melanoma cell growth. So, RU-486 dosecurve study was carried out with melanoma cells. RU-486 also showed a dose-dependent inhibition of melanoma cell growth similar to that of progesterone. In fact, RU-486 was more inhibitory to melanoma cell growth than progesterone itself (Figure 2(c)). 
Table 1. Effect of various sex steroids at different concentrations on mouse melanoma cell growth. Two-way ANOVA analysis comprising dosage and sex hormones as two variables, followed by post-hoc Bonferroni multiple comparison test, indicated that cell growth inhibition by progesterone at 100 and $150 \mu \mathrm{M}$ were significant $(\mathrm{P}<0.001)$ when compared to DHEA, $\mathrm{AD}$, and $\mathrm{T}$ at different concentrations.

\begin{tabular}{|c|c|c|c|c|}
\hline Dossage & Drug & Drug & Mean difference (\% of cell Growth) & Significance \\
\hline \multirow{12}{*}{$100 \mu \mathrm{M}$} & \multirow{3}{*}{ DHEA } & Androstenedione & 12.214 & 0.087 \\
\hline & & Testosterone & -7.506 & 0.71 \\
\hline & & Progesterone & 33.333 & $<0.001$ \\
\hline & \multirow{4}{*}{ Androstenedione } & DHEA & -12.214 & 0.087 \\
\hline & & Testosterone & -19.720 & 0.002 \\
\hline & & Progesterone & 21.119 & 0.001 \\
\hline & & DHEA & 7.506 & 0.71 \\
\hline & \multirow[t]{3}{*}{ Testosterone } & Androstenedione & 19.720 & 0.002 \\
\hline & & Progesterone & 40.839 & $<0.001$ \\
\hline & & DHEA & -33.333 & $<0.001$ \\
\hline & \multirow{3}{*}{ Progesterone } & Androstenedione & -21.119 & $<0.001$ \\
\hline & & Testosterone & -40.839 & $<0.001$ \\
\hline \multirow{12}{*}{$150 \mu \mathrm{M}$} & & Androstenedione & 17.343 & 0.006 \\
\hline & \multirow[t]{3}{*}{ DHEA } & Testosterone & 5.594 & 1 \\
\hline & & Progesterone & 44.196 & $<0.001$ \\
\hline & & DHEA & -17.343 & 0.006 \\
\hline & \multirow[t]{3}{*}{ Androstenedione } & Testosterone & -11.748 & 0.109 \\
\hline & & Progesterone & 26.853 & $<0.001$ \\
\hline & & DHEA & -5.594 & 1 \\
\hline & \multirow[t]{3}{*}{ Testosterone } & Androstenedione & 11.748 & 0.109 \\
\hline & & Progesterone & 38.601 & $<0.001$ \\
\hline & & DHEA & -44.196 & $<0.001$ \\
\hline & \multirow[t]{3}{*}{ Progesterone } & Androstenedione & -26.853 & $<0.001$ \\
\hline & & Testosterone & -38.601 & $<0.001$ \\
\hline \multirow{12}{*}{$200 \mu \mathrm{M}$} & & Androstenedione & 16.037 & 0.012 \\
\hline & \multirow[t]{3}{*}{ DHEA } & Testosterone & 23.030 & $<0.001$ \\
\hline & & Progesterone & 32.587 & $<0.001$ \\
\hline & & DHEA & -16.037 & 0.012 \\
\hline & \multirow[t]{2}{*}{ Androstenedione } & Testosterone & 6.993 & 0.866 \\
\hline & & Progesterone & 16.550 & 0.009 \\
\hline & \multirow{4}{*}{ Testosterone } & DHEA & -23.030 & $<0.001$ \\
\hline & & Androstenedione & -6.993 & 0.866 \\
\hline & & Progesterone & 9.557 & 0.301 \\
\hline & & DHEA & -32.587 & $<0.001$ \\
\hline & \multirow[t]{2}{*}{ Progesterone } & Androstenedione & -16.550 & 0.009 \\
\hline & & Testosterone & -9.557 & 0.301 \\
\hline
\end{tabular}

The mean difference is significant at the $<0.050$ level. Adjustment for multiple comparisons: Bonferroni. 


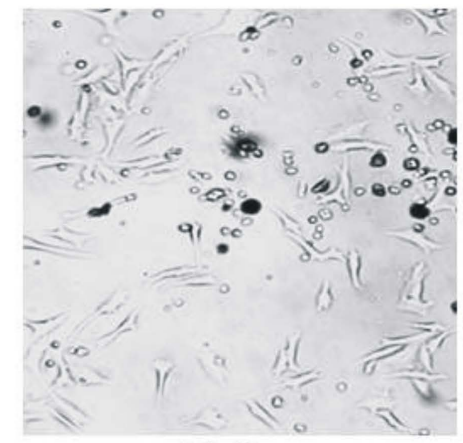

$100 \mu \mathrm{M}$

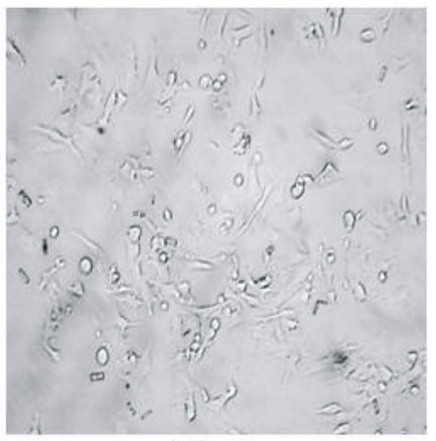

$100 \mu \mathrm{M}$
RU-486

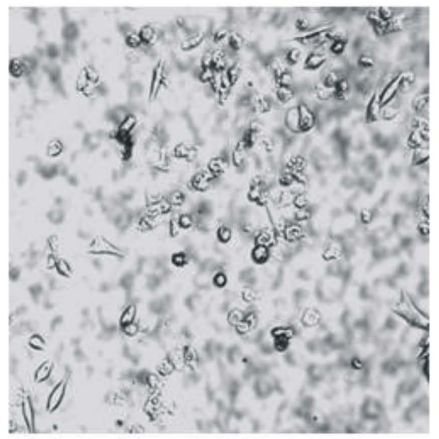

$100 \mu \mathrm{M}$

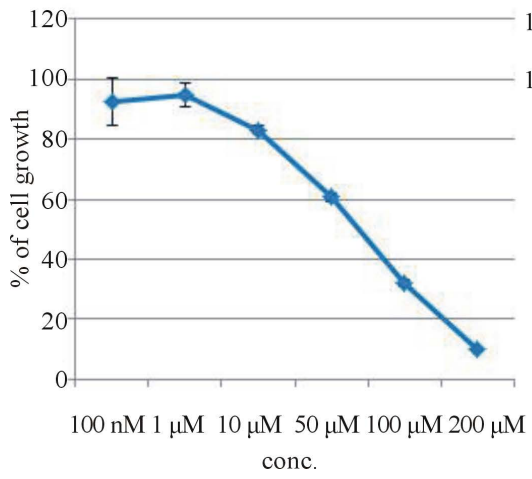

(a)

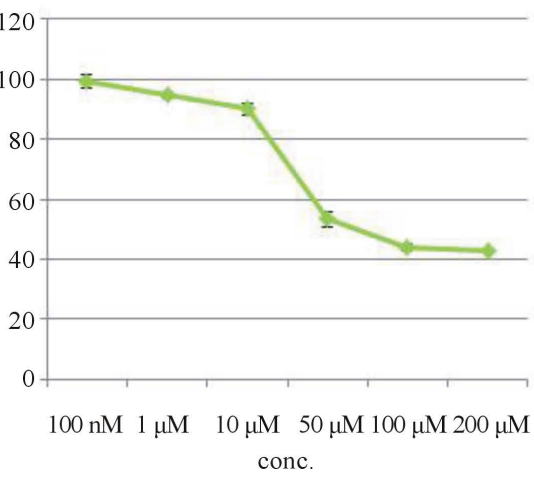

(b)

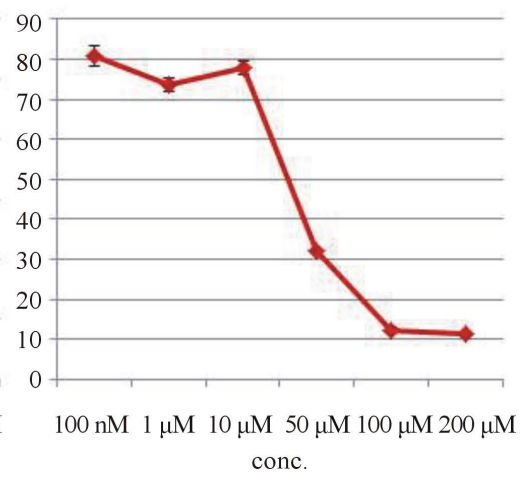

(c)

Figure 2. Dose-curve studies with steroids (progesterone, estrogen and RU-486) to check for toxic effect. Cells were treated with steroid hormones as stated in methods and MTT assays were carried out. (a) Dose-curve study with progesterone starting from $100 \mathrm{nM}$ to $200 \mu \mathrm{M}$ showed a dose-dependent inhibition of cell growth; (b) Dose-curve study with estrogen also showed dose-dependent inhibition of melanoma cell growth; (c) Progesterone receptor antagonist RU-486 also showed a significant dose-dependent inhibition of mouse melanoma cell growth.

\subsection{Dose Curve Studies with Cholesterol and Dexamethasone to Check for Spurious Effect of Steroids on Melanoma Cell Growth}

Dose-dependent inhibition of mouse melanoma cell growth by three steroids (P, E, RU-486), gave rise to the apprehension that it could be a spurious effect associated with general steroid structure. The following dosecurve studies were carried out to check for spurious effect of steroid on melanoma cell growth inhibition.

\subsubsection{Dose-Curve Study with Cholesterol}

In order to rule out that the steroid growth inhibition was a spurious effect associated with the structure of steroid, dose curve study with cholesterol, the parent molecule of all steroids was carried out. Dose-curve study with cholesterol showed initially a slight inhibition, but, that plateaued from $1 \mu \mathrm{M}$ up to $200 \mu \mathrm{M}$. There was no significant inhibition of growth brought about by cholesterol (Figure 3(a)). So the inhibition by progesterone was not due to any spurious effect of the steroid on mouse melanoma cell growth.

\subsubsection{Dose-Curve Study with Dexamethasone}

RU-486 is also an antagonist to glucocorticoid receptor. It has already been shown that glucocorticoid receptors are present in B16 melanoma cells [18]. So, it was decided to check the effect of dexamethasone (water soluble) an agonist of glucocorticoid receptor on melanoma cell growth. From low concentration (100 nM) to high concentration $(200 \mu \mathrm{M})$ there was a plateau indicating that glucocorticoid receptor was not involved in the regulation of B16F10 in-vitro cell growth (Figure 3(b)). Similar observation was also reported by Crowley et al. [19]. 


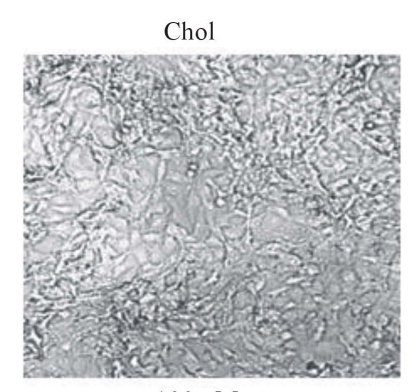

$100 \mu \mathrm{M}$

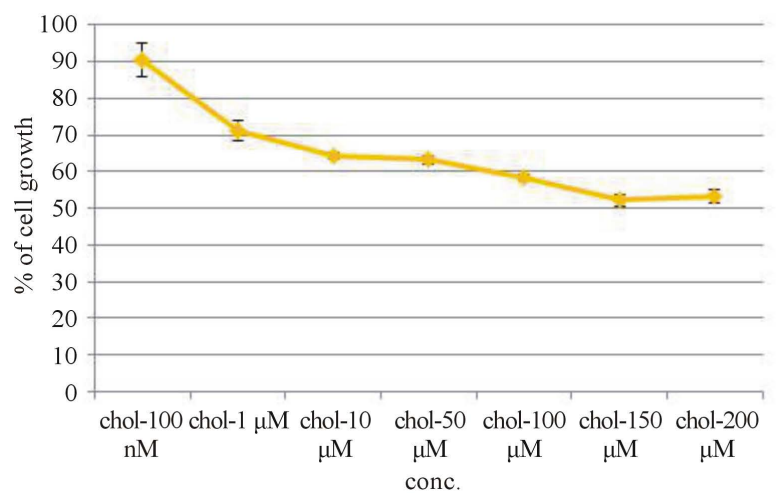

(a)

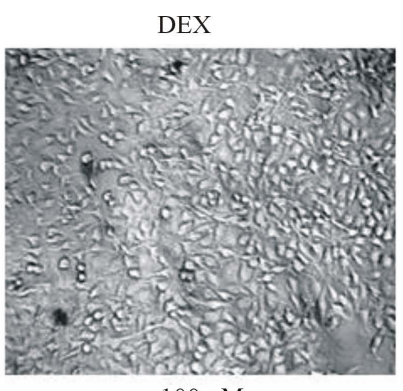

$100 \mu \mathrm{M}$

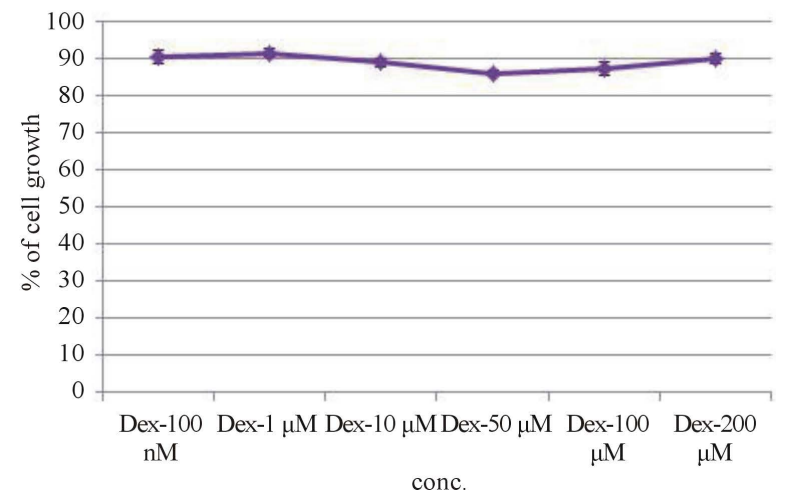

(b)

Figure 3. Dose-curve studies with cholesterol and dexamethasone to check for spurious effect of steroids on melanoma cell growth inhibition. (a) Cholesterol showed slight inhibition at $1 \mu \mathrm{M}$, but subsequently it plateaued till $200 \mu \mathrm{M}$, indicating that the inhibition observed with steroids was not due to any spurious effect associated with steroid such as structure or orientation of functional groups; (b) There was no dose-dependent inhibition of cell growth with dexamethasone even at high concentration $(200 \mu \mathrm{M})$, indicating that glucocorticoid receptor was not involved in the regulation of B16F10 in-vitro cell growth.

\subsection{Dose Curve Studies of Progesterone and RU-486 on Human Gastric Cancer (NUGC3) Cell Line and Sub-Cultured Normal Rat Vascular Smooth Muscle Cells (VSMC) to Check for Non-Specific Effect of Steroids on Melanoma Cell Growth}

One way to determine non-specific effect of progesterone was to test on a different cell line or cells from different species, because whatever effect was observed with mouse model need not be reproduced in another cell line or cells from another specie [20]. So, human gastric cancer cell line and sub-cultured normal rat vascular smooth muscle cells were used to check for non-specific effects of progesterone and RU-486 on cell growth inhibition.

\subsubsection{Effect of Progesterone and RU-486 on Human Gastric Cancer (NUGC3) Cell Growth}

In order to answer the question, whether the inhibition by Progesterone and RU-486 was a non-specific effect common in other cancer cell lines, dose-curve studies of progesterone and RU-486 on human gastric cancer cell line (NUGC3) were carried out. Though there was a slight inhibition on gastric cancer cell growth (Figure 4(a)), it was not as significant as that of progesterone and RU-486 effects on melanoma cell growth, indicating inhibition of melanoma cell growth by progesterone was not due to non-specific effect of the steroid.

\subsubsection{Effect of Progesterone and RU-486 on Sub-Cultured Normal Rat Vascular Smooth Muscle Cell (VSMC) Growth}

For checking non-specific effect of steroids, it was felt appropriate to use non-mouse and an uncommon cell type. So, sub-cultured normal rat vascular smooth muscle cells were used to carry out dose curve studies with progesterone and RU-486. Since smooth muscle cells were derived from normal rat, sub-cultured vascular smooth muscle cells also served as control cells to answer the question about the effect of progesterone and RU486 on normal cells. After 48 hours of incubation with steroids, cell growth was assessed by MTT assay. Proge- 


\section{NUGC3}

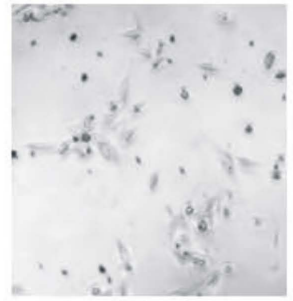

Prog-100 $\mu \mathrm{M}$

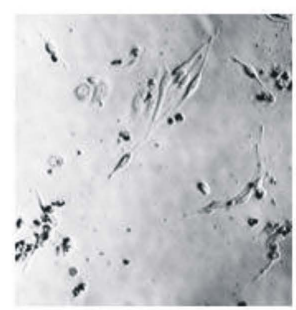

RU-100 $\mu \mathrm{M}$

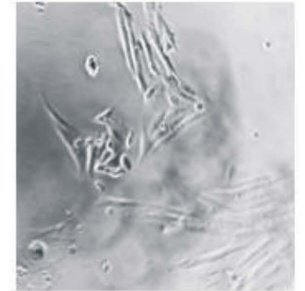

Prog-50 $\mu \mathrm{M}$
VSMC

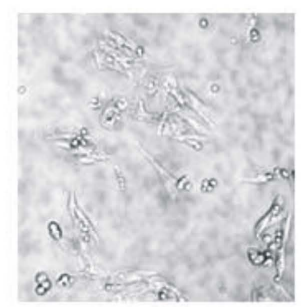

RU-50 $\mu \mathrm{M}$

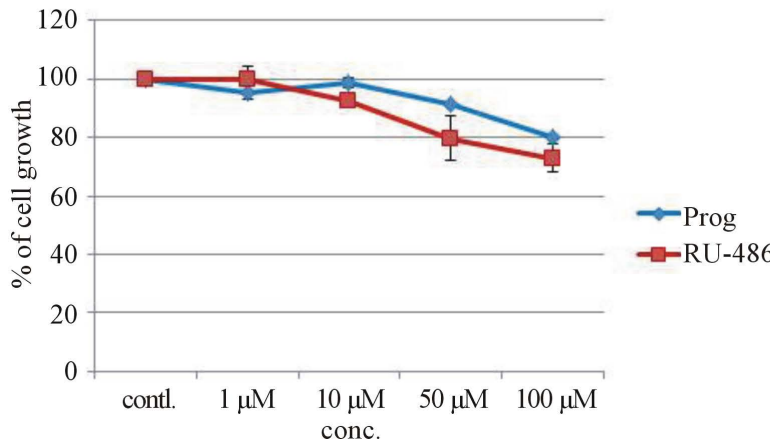

(a)

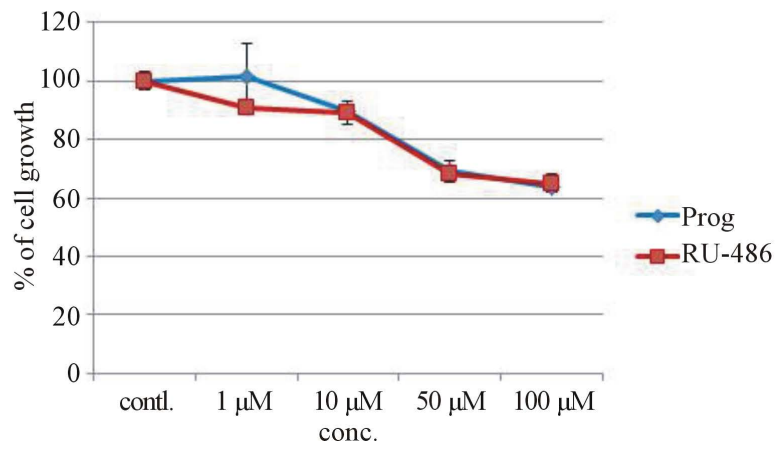

(b)

Figure 4. Dose-curve studies with progesterone and RU-486 on human gastric cancer cell line and sub-cultured normal rat vascular smooth muscle cells to check for non-specific effect of steroids on melanoma cell growth. (a) Gastric cancer cell line (NUGC3) from human was used to check whether the effect was due to non-specific inhibition of cancer cell line. There was a slight inhibition on cell growth; (b) To find out non-specific effect of steroids on normal cell, sub-cultured normal rat vascular smooth muscle cells were used. There was a slight inhibition of cell growth.

sterone and RU-486 showed a slight inhibition on VSMC growth (Figure 4(b)), but not like the effect on mouse melanoma cell growth.

\subsection{Comparison of Dose-Response Curves of Various Steroids and the Plausible Mechanism of Action of Progesterone on B16F10 Cells}

When dose response curves of various steroids and cholesterol were plotted on the same graph (Figure 5(a)), only progesterone and its receptor antagonist RU-486 showed significant inhibition on mouse melanoma cell growth (Figure 5(b)). This observation warranted our attention to the mechanism of action of these two steroids and prompted us to check for the involvement of progesterone receptor in the inhibition of melanoma cell growth.

\subsection{Progesterone and RU-486 Co-Incubation-A Bioassay to Check for the Involvement of Progesterone Receptor in Mediating Progesterone Action on B16F10 Cells}

Mifepristone or RU-486 is an antagonist to progesterone receptor. Since progesterone and RU-486 separately showed dose-dependent inhibition on melanoma cell growth, co-incubation of progesterone and RU-486 was crucial to determine the involvement of progesterone receptor. Cells were co-incubated with $50 \mu \mathrm{M}$ of progesterone and different concentrations of RU-486 $(50 \mu \mathrm{M}, 100 \mu \mathrm{M}$ and $150 \mu \mathrm{M})$ and appropriate individual controls to compare the effect on cell growth. Co-incubation experiments showed that $50 \mu \mathrm{M}$ of progesterone +50 $\mu \mathrm{M}$ of RU-486 showed an inhibition level similar to the inhibition by RU-486 alone at high $150 \mu \mathrm{M}$ concentration, indicating it was an additive effect of steroids on the inhibition of melanoma cell growth (Figure 6). Moreover, the same co-incubation experiment also suggested that the effect on cell growth was probably not mediated through progesterone receptor. Statistical analysis of the significance $(P<0.001)$ of inhibition on cell growth by a combination of steroid hormones was shown in Table 2. 
$\mathrm{B} 16 \mathrm{~F} 10$

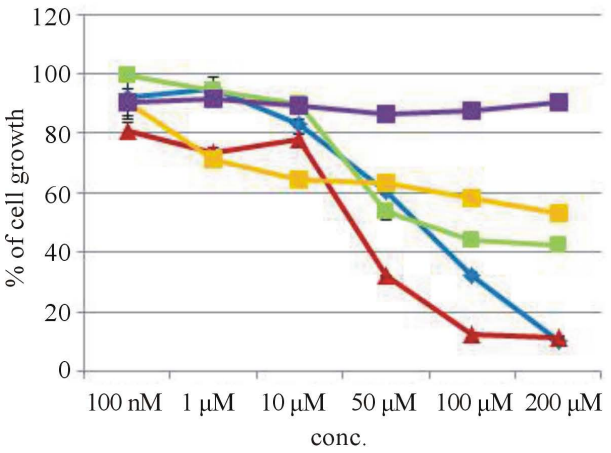

(a)
B16F 10

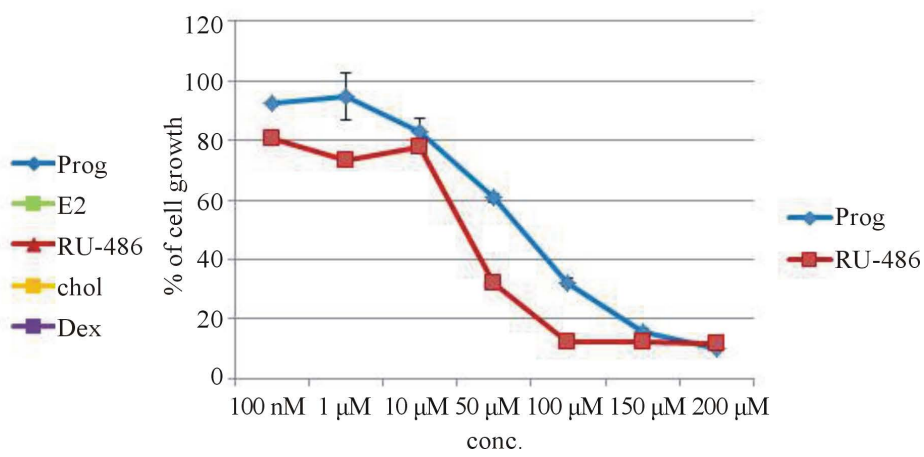

(b)

Figure 5. Comparison of dose-curve studies of various steroids on mouse melanoma cell line. (a) Dose-curve studies of various steroids on melanoma cells were compared. Only two steroids progesterone and its synthetic receptor antagonist RU-486 showed maximum inhibition on melanoma cell growth; (b) Comparison of dose-curve studies between progesterone and its receptor antagonist RU-486 showed that RU-486 was more inhibitory on melanoma cell growth than progesterone itself.

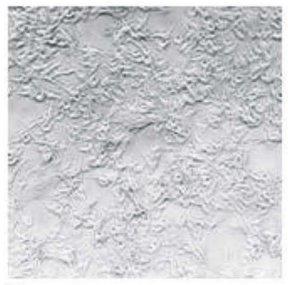

Contl

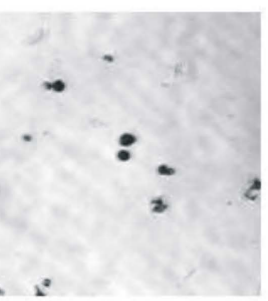

P-50 $\mu \mathrm{M}+\mathrm{RU}-100 \mu \mathrm{M}$

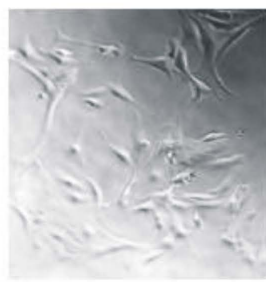

$\mathrm{P}-50 \mu \mathrm{M}$
$\mathrm{B} 16 \mathrm{~F} 10$

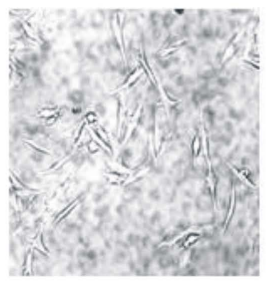

$\mathrm{RU}-50 \mu \mathrm{M}$

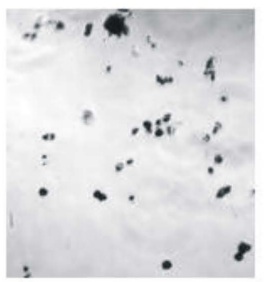

RU-150 $\mu \mathrm{M}$

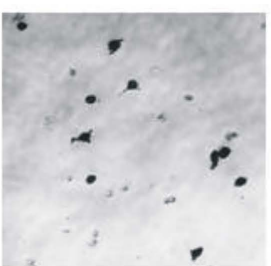

$\mathrm{P}-50 \mu \mathrm{M}+\mathrm{RU}-50 \mu \mathrm{M}$
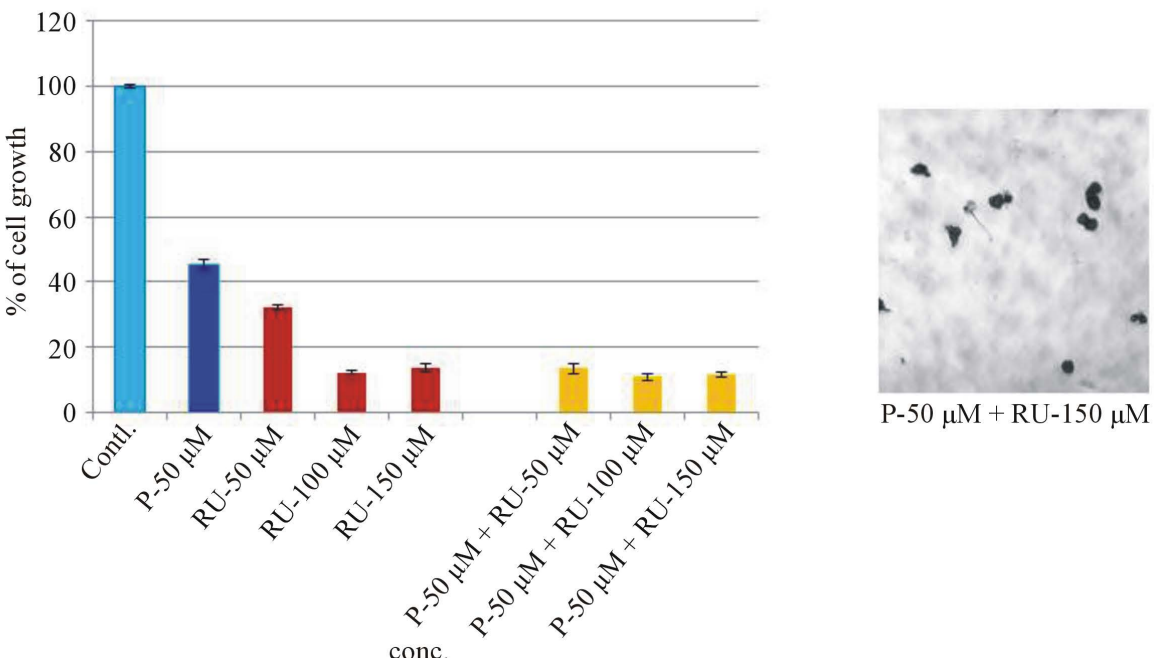

$\mathrm{P}-50 \mu \mathrm{M}+\mathrm{RU}-150 \mu \mathrm{M}$

Figure 6. Bioassay: Co-incubation of Progesterone and RU-486 on B16 melanoma cell growth. To find out the mechanism of progesterone action on melanoma cell growth, progesterone and RU-486 were co-incubated. Fixed concentration of progesterone $(50 \mu \mathrm{M})$ was co-incubated with various concentrations of RU-486 (50, 100, $150 \mu \mathrm{M})$. For control purpose, progesterone and RU-486 were incubated alone with melanoma cells to compare their effect on co-incubation.

\section{Discussion}

It has been shown that sex steroids (androgens, estrogens and progesterone) are essential for healthy skin [3], hence skin is a target organ for sex steroids. It has also been shown that sex steroids such as estrogen, progesterone and testosterone support cancer growth in conditions such as breast, ovary and prostate cancers [8]-[10], 
Table 2. Bioassay: Progesterone and RU-486 co-incubation on melanoma cell growth. One-way ANOVA analysis, followed by post-hoc HSD test indicated that the difference in cell growth between progesterone $(\mathrm{P}-50 \mu \mathrm{M})$ and the combined (P-50 $\mu \mathrm{M}+\mathrm{RU}-50 \mu \mathrm{M})$ hormones was significant $(\mathrm{P}<0.001)$. Similarly the difference in cell growth between RU-486 (RU-50 $\mu \mathrm{M})$ and combined hormones was also significant $(\mathrm{P}<0.001)$.

\begin{tabular}{cccc}
\hline (I) Drug & (J) Drug & $\begin{array}{c}\text { Mean difference (I-J) } \\
\text { (\% of cell growth) }\end{array}$ & Significance \\
\hline \multirow{2}{*}{ P-50 $\mu \mathrm{M}$} & Combined & 32.059 & $<0.001$ \\
& Ru-50 $\mu \mathrm{M}$ & 13.904 & 0.001 \\
Combined & $\mathrm{P}-50 \mu \mathrm{M}$ & -32.059 & $<0.001$ \\
& $\mathrm{Ru}-50 \mu \mathrm{M}$ & -18.154 & $<0.001$ \\
Ru-50 $\mu \mathrm{M}$ & $\mathrm{P}-50 \mu \mathrm{M}$ & -13.904 & 0.001 \\
& Combined & 18.154 & $<0.001$ \\
\hline
\end{tabular}

even though these steroid hormones are needed for normal growth, development and function of these organs. It is not clear whether the same is true for sex steroid hormones on melanoma, cancer of the melanocytes. But epidemiological and animal studies showed a dependence of melanoma growth on hormones [5]-[7]. Hence, invitro growth assays were carried out with various sex steroids using mouse melanoma cell line as a model system. Progesterone was found to inhibit melanoma cell growth significantly. The two main outcomes of the study were:

\subsection{Progesterone Inhibition of Melanoma Cell Growth Was Not a Toxic, Spurious or Non-Specific Effect}

Among the four steroids tested for their effect on mouse melanoma cell growth, progesterone showed maximum inhibition on cell growth. Inhibition of cancer cell growth by progesterone warranted further research work to find out if the inhibition was due to toxic, spurious or non-specific effect of steroids. Progesterone dose curve study showed it was not a toxic effect, but a genuine biological effect because of sigmoidal response curve. Dose curve studies with estrogen and RU-486, which also showed dose-dependent inhibition, raised the apprehension that it could be a spurious effect associated with sex steroids. However, dose-curve study with cholesterol, the parent molecule of all steroids showed it was not a spurious effect. Dose curve studies of progesterone and RU-486 on human gastric cancer cell line showed the effect on cell growth was not a non-specific effect of progesterone on cancer cells. Similarly dose-curve studies with sub-cultured normal rat vascular smooth muscle cells indicated that the inhibition of melanoma cell growth by progesterone was not a non-specific effect. It is appropriate to point out at this context that menstruating females are better protected in melanoma than postmenopausal women and men of any age groups [21] [22].

\subsection{Progesterone Effect Was Not Mediated through Progesterone Receptor}

Since progesterone and its receptor antagonist RU-486 independently showed inhibition on mouse melanoma cell growth, there was a suspicion that the action could be mediated through progesterone receptor. But literature survey showed the action could not be mediated through progesterone receptor. Researchers were not able to identify progesterone receptor through immunohistochemical staining [23], even though previous researchers showed binding of progesterone in melanoma through biochemical assay [24]. Moreover, one study [25] showed that there was no evidence of progesterone receptor in B16 cell lines. Hence, biological or bioassay was the only option left to check whether the action was mediated through progesterone receptor. Bioassay involving co-incubation of progesterone and its receptor antagonist RU-486 showed an additive effect on the inhibition of cell growth. If the inhibition were to take place through progesterone receptor, progesterone and RU-486 would compete for the limited progesterone receptors and in the process nullifying the effect of one another leaving the cells to grow. Thus there would be an increase in cell growth and not a decrease in cell growth. But, additive effect of steroids on the inhibition of cell growth indicated that each steroid acted through different mechanism and the action was not mediated through progesterone receptor. In this context, it is important to point out that a similar in-vitro observation was made with progesterone and RU-486 on human neuroblastoma [26]. Back references from the paper showed similar observations were made on other cell lines with progesterone and RU- 
486 [27]. One interesting point to note is that the nervous system and skin (integumentary system) are derived from the same germ layer and cancer cells derived from both systems (neuroblastoma and melanoma) showed inhibition by progesterone and RU-486, which was not mediated through progesterone receptor.

\section{Conclusion}

In conclusion, progesterone inhibited mouse melanoma cell growth, which was not a toxic, spurious or non-specific action of progesterone and this action of progesterone was not mediated through progesterone receptor. Future research work will be focused on progesterone and RU-486 separately to determine the mechanism of inhibition of cell growth.

\section{Acknowledgements}

This work was supported by a start-up grant (grant \# 261-200-889) from KCOM and Warner/Fermaturo intramural grant (grant \# 261-8530-501392) from A.T. Still University to P.R. Gift of sub-cultured normal rat vascular smooth muscle cells by Dr. Yingzi Chang is gratefully acknowledged. Help with statistical analysis by Seth Mclntire, a graduate student in the dept. is also acknowledged. Technical assistance in manuscript preparation by Sujatha Bhuvanaraj is duly acknowledged.

\section{References}

[1] Ramaraj, P. and Cox, J.L. (2011) Effect of Steroids on in-Vitro Melanoma Cell Growth and Viability. Endocrine Reviews, 12, 1-29 (Abstract).

[2] Zouboulis, C.C. (2004) The Human Skin as a Hormone Target and an Endocrine Gland. Hormones, 3, 9-26. http://dx.doi.org/10.14310/horm.2002.11109

[3] Zouboulis, C.C., Chen, W.C., Thornton, M.J., Qin, K. and Rosenfield, R. (2007) Sexual Hormones in Human Skin. Hormone and Metabolic Research, 39, 85-95. http://dx.doi.org/10.1055/s-2007-961807

[4] Gray-Schopfer, V., Wellbrock, C. and Marais, R. (2007) Melanoma Biology and New Targeted Therapy. Nature, 445, 851-857. http://dx.doi.org/10.1038/nature05661

[5] White, L.P. (1959) Studies on Melanoma-II Sex and Survival in Human Melanoma. New England Journal of Medicine, 260, 789-797. http://dx.doi.org/10.1056/NEJM195904162601601

[6] Bodenham, D.C. and Hale, B. (1972) Malignant Melanoma, Endocrine Therapy in Malignant Disease. In: Stoll, B.A., Ed., W.B. Saunders Co. Ltd., London, 377-383.

[7] Neifeld, J.P. and Lippman, M.E. (1980) Steroid Hormone Receptors and Melanoma. Journal of Investigative Dermatology, 74, 379-381. http://dx.doi.org/10.1111/1523-1747.ep12544454

[8] Zhao, Y., Deng, C., Lu, W., Xiao, J., Ma, D., Guo, M., Recker, R.R., Gatalica, Z., Wang, Z. and Xiao, G.G. (2011) Let-7 microRNAs Induce Tamoxifen Sensitivity by Downregulation of Estrogen Receptor- $\alpha$ Signaling in Breast Cancer. Molecular Medicine, 17, 1233-1241. http://dx.doi.org/10.2119/molmed.2010.00225

[9] Liu, T., Chen, L., Sun, X., Wang, Y., Li, S., Yin, X., Wang, X., Ding, C., Li, H. and Di, W. (2014) Progesterone Receptor PROGINS and +331G/A Polymorphisms with Ovarian Cancer Susceptibility to Ovarian Cancer: A Meta-Analysis Based on 17 Studies. Tumor Biology, 35, 2427-2436. http://dx.doi.org/10.1007/s13277-013-1322-X

[10] Ming, D.S., Pham, S., Deb, S., Chin, M.Y., Kharmate, G., Adomat, H., Beheshti, E.H., Locke, J. and Guns, E.T. (2014) Pomegranate Extracts Impact the Androgen Biosynthesis Pathways in Prostate Cancer Models in Vitro and in Vivo. The Journal of Steroid Biochemistry and Molecular Biology, 143C, 19-28. http://dx.doi.org/10.1016/j.jsbmb.2014.02.006

[11] Mather, J.P. and Sato, G.H. (1979) The Growth of Mouse Melanoma Cells in Hormone-Supplemented, Serum-Free Medium. Experimental Cell Research, 120, 191-200. http://dx.doi.org/10.1016/0014-4827(79)90549-4

[12] Pavelic, K., Petrusic, L., Osmak, M. and Culo, F. (1983) In Vivo and in Vitro Effect of Progesterone on the Growth of Some Mouse and Human Tumors. Research in Experimental Medicine, 183, 183-191. http://dx.doi.org/10.1007/BF01855641

[13] Kanda, N. and Watanabe, S. (2001) 17 $\beta$-Estradiol, Progesterone and Dihydrotestosterone Suppress the Growth of Human Melanoma by Inhibiting Interleukin-8 Production. Journal of Investigative Dermatology, 117, 274-283. http://dx.doi.org/10.1046/j.1523-1747.2001.01422.x

[14] Ranson, M., Posen, S. and Mason, R.S. (1988) Human Melanocytes as a Target Tissue for Hormones: In Vitro Studies with $1 \alpha$-25 Dihydroxy Vitamin $\mathrm{D}_{3}, \alpha$-Melanocyte Stimulating Hormone and $\beta$-Estradiol. Journal of Investigative Der- 
matology, 91, 593-598. http://dx.doi.org/10.1111/1523-1747.ep12477126

[15] Cos, S., Garcia-Bolado, A. and Sanchez-Barcelo, E.J. (2001) Direct Antiproliferative Effects of Melatonin on Two Metastatic Cell Sub-Lines of Mouse Melanoma (B16BL6 and PG19). Melanoma Research, 11, 197-201.

[16] Denzit, F. and Lang, R. (1986) Rapid Colorimetric Assay for Cell Growth and Survival, Modifications to the Tetrazolium Dye Procedure Giving Improved Sensitivity and Reliability. Journal of Immunological Methods, 89, 271-277.

[17] Brown, C., Pan, X. and Hassid, A. (1999) Nitric Oxide and C-Type Atrial Natriuretic Peptide Stimulate Primary Aortic Smooth Muscle Cell Migration via a cGMP-Dependent Mechanism: Relationship to Microfilament Dissociation and Altered cell Morphology. Circulation Research, 84, 655-667. http://dx.doi.org/10.1161/01.RES.84.6.655

[18] Bhakoo, H.S., Paolini, N.S., Milholland, R.J., Lopez, R.E. and Rosen, F. (1981) Glucocorticoid Receptors and the Effect of Glucocorticoids on the Growth of B16 Melanoma. Cancer Research, 41, 1695-1701.

[19] Crowley, P., Lai, N.Y., De Young, N., Pearce, P., Funder, J.W. and Gill, P.G. (1998) Inhibition of Growth of B16 Melanoma by Glucocorticoids Does Not Result Directly from Receptor Mediated Inhibition of Tumor Cells. Oncology, 45, 331-335. http://dx.doi.org/10.1159/000226634

[20] Dhatariya, K.K. and Nair, K.S. (2003) Dehydroepiandrosterone: Is There a Role for Replacement? Mayo Clinic Proceedings, 78, 1257-1273. http://dx.doi.org/10.4065/78.10.1257

[21] Kemeny, M.M., Busch, E., Stewart, A.K. and Menck, H.R. (1998) Superior Survival of Young Women with Malignant Melanoma. The American Journal of Surgery, 175, 437-445. http://dx.doi.org/10.1016/S0002-9610(98)00070-1

[22] Richardson, B., Price, A., Wagner, M., Williams, V., Lorigan, P., Browne, S., Miller, J.G. and Mac Neil, S. (1999) Investigation of Female Survival Benefit in Metastatic Melanoma. British Journal of Cancer, 80, 2025-2033. http://dx.doi.org/10.1038/sj.bjc.6690637

[23] Duncan, L.M., Travers, R.L., Koerner, F.C., et al. (1994) Estrogen and Progesterone Receptor Analysis in PregnancyAssociated Melanoma: Absence of Immunohistochemically Detectable Hormone Receptors. Human Pathology, 25, 3641. http://dx.doi.org/10.1016/0046-8177(94)90168-6

[24] Neifeld, J.P. and Lippman, M.E. (1976) Fisher RI: Receptors for Steroid Hormones in Human Melanoma. Surgical Forum, 27, 108-110.

[25] Markland, F.S. and Horn, D. (1980) Steroid Hormone Receptor Studies in Melanoma Model Systems. Journal of Supramolecular Structure, 13, 35-46. http://dx.doi.org/10.1002/jss.400130104

[26] Atif, F., Sayeed, I., Yousuf, S., Ishrat, T., Hua, F., Wang, J., Brat, D.J. and Stein, D.G. (2011) Progesterone Inhibits the Growth of Human Neuroblastoma: In Vitro and in Vivo Evidence. Molecular Medicine, 17, 1084-1094. http://dx.doi.org/10.2119/molmed.2010.00255

[27] Fjelldal, R., Moe, B.T., Orbo, A. and Sayer, C. (2010) MCF-7 Cell Apoptosis and Cell Cycle Arrest: Non-Genomic Effects of Progesterone and Mifepristone (RU-486). Anticancer Research, 30, 4835-4840.

\section{Abbreviations}

DHEA-dehydroepiandrosterone

DHEAS—dehydroepiandrosterone sulfate

DHT-dihydrotestosterone

$\mathrm{T}$-testosterone

E-estrogen

$\mathrm{P}$-progesterone

$\mathrm{AD}$-androstenedione

DEX-dexamethasone

Chol-cholesterol

RU-486-also known as mifepristone

MTT-(3-[4,5-Dimethylthiazol-2-yl]-2,5-diphenyl tetrazolium bromide)

VSMC—-vascular smooth muscle cell

ANOVA-analysis of variance 